\title{
The tundras and steppes of prehistoric Europe
}

\author{
Professor James Geikie D.C.L., LL.D., F.R.S.
}

To cite this article: Professor James Geikie D.C.L., LL.D., F.R.S. (1898) The tundras and steppes of prehistoric Europe, Scottish Geographical Magazine, 14:7, 346-357, DOI: 10.1080/00369229808733003

To link to this article: http://dx.doi.org/10.1080/00369229808733003

曲 Published online: 27 Feb 2008.

Submit your article to this journal $₫$

Џlll Article views: 4

Q View related articles ¿ 
from the water the frozen ground prevents the proper development of trees. The season during which they can grow is very short, and the ground on which they grow is continually frozen. These conditions result in the growth of trees from three to six inches in diameter, which are found to be several centuries old, if we count the growth-rings, one of which generally stands for a year's growth. All commercial timber will necessarily soon become exhausted, and the sooner coal-mining is taken up the better for all concerned. This offers a safe investment to capitalists.

Other minerals are found in limited quantities in the Yukon country : galena, near Fortymile, yielding upwards of thirty oz. of silver per ton of ore; a crude form of asbestos occurs in the same vicinity; copper on White river, and traces of it at several points along the Lewes. Silver has been found in the drift on some of the streams near the head of the Lewes, and it has been declared that an extensive lode of silver ore has been found in the vicinity of Bennet lake. All these conjoined go to show that the future of that country will be much more bright and cheerful than its gloomy, inhospitable surface and long, cold, dark winters would at present indicate. There is a vast field here for a reasonably safe investment of British capital and influence; and attention is cordially invited to it by the people of Canada, not the least part of this vast Empire.

The preceding compilation from my records of temperature convey an idea of the range of temperature, and duration of the seasons. It can truthfully be said that while it is cold it is not unhealthy, nor so disagreeable as might be thought from the low thermometer readings shown.

\title{
THE TUNDRAS AND STEPPES OF PREHISTORIC EUROPE.
}

\author{
By Professor Janies Geikie, D.C.L., LL.D., F.R.S.
}

(Continued from page 294.)

(With a Map.)

\section{II. ${ }^{1}$}

IN my preceding lecture evidence was adduced to show that tundras and steppes, with their characteristic faunas, formerly existed in Central and West-central Europe. We saw that for a long time the climatic conditions of these regions must have resembled those that now obtain in Northern Siberia and the barren grounds of North America, where mosses and lichens form the prevailing growths, and arctic lemmings, hares, and foxes, the reindeer, and the musk-ox, are the common indigen-

1 A Lecture delivered before the Royal Dublin Society, 11th March 1898. 
ous animals. All these characteristic species formerly lived in Middle Europe. Eventually our tundra flora and fauna gradually disappeared and were as gradually replaced by steppe forms of life. Jerboas, pouched marmots, pika, and many others-such an assemblage as we now see in the sub-arctic steppes of south-east Russia and south-west Siberiaflourished throughout the regions over which the lemmings and their arctic congeners had formerly prevailed. Throughout both tundra and steppe epochs Palæolithic man was an occupant of Middle Europe. To the steppe epoch succeeded a forest epoch, with its characteristic. fauna, by which time Palæolithic man had vanished, his place being taken by the so-called Neolithic race, or races, for there were several of these.

We must now ask what relation the tundra and steppe deposits bear to other well-known superficial accumulations of Europe. To what particular stage of the geological history of our continent do they belong? When we remember that an arctic-alpine flora formerly flourished on the low grounds of Central Europe, it seems extremely probable that the tundra epoch must fall within the Glacial Period. But the Glacial Period embraced a complex series of geographical and climatic changes, and it is necessary, therefore, to cone somewhat closer to the question. Among the most conspicuous deposits of the Ice Age are moraines of all kinds and fluvio-glacial gravels, while the löss, as we have seen, is the most prominent accumulation of the tundra and steppe epochs. How, then, does the latter behave with regard to the typical glacial and fluvioglacial formations? Is it older or younger than these, or are the two sets of accumulations contemporaneous? The answer we get to that question is, at the first blush, disconcerting, for we learn that it is each in turn-sometimes underlying, sometimes overlying, and in other places occurring intercalated amongst glacial deposits. This only means, however, that löss appears to have been formed during different stages of the Ice Age. It will be remembered that while we discussed the wind-blown character of the löss, we left untouched the question of the origin of its materials. Whence were those materials derived which the wind worked over, and largely re-arranged, and re-distributed in the low grounds of Central Europe? To answer this question we must examine more closely the relation borne by the löss to the fluvio-glacial deposits and morainic accumulations. We note, in the first place, that in its horizontal distribution it follows closely that of the valley-gravels of glacial-times. Where the latter are well developed, the löss appears in full force; where they are wanting there is a like absence of löss. In all the valleys leading down from the Alps to the low grounds of Middle Europe the löss puts in a prominent appearance. It obviously bears a close relation to the main lines of drainage, and may be said to be confined to valleys that head in formerly glaciated areas. So again, in North Germany and Southern Russia, it spreads over all the low-lying tracts that lay in front of the vast mers de glace of glacial times. These facts alone, taken in connection with the occasional well-stratified character of the löss, the intercalation in it now and again of beds of sand, and the presence ever and anon of freshwater shells, seem strongly suggestive of a fluviatile origin. And that such was really the origin of the 
materials of the löss will appear clear enough when we consider the conditions that obtained during a glacial epoch. (See Map A.)

While all Northern and North-western Europe were covered by' an ice-sheet, the mountains of Middle Europe and the Alpine Lands supported great glaciers, which in many cases deployed upon the low grounds. Vast bodies of water must then have escaped from the terminal front of the northern mer de glace, while the streams and rivers flowing from our mountain tracts must have greatly exceeded their present successors. With each recurring spring and summer wide areas in the low grounds would thus be subject to floods and inundations. Coming from regions where glacial grinding was being carried on upon a most extensive scale, it goes without saying that all these waters. would be clouded with the fine flour of rocks. The enormous morainic accumulations formed underneath and in front of the Alpine glaciers, and over the vast areas traversed by the Scandinavian mer de glace, bear emphatic testimony to the intensity of glacial erosion. In like manner the great terraces of gravel that stretch down the valleys in front of the Alpine moraines and the broad sheets of similar. deposits which extend outwards from the glaciated tracts of Northern Europe, are equally impressive witnesses to the vigour of the flooded glacial rivers. It is certain, however, that gravel, grit, and sand would not be the only materials carried forward by those rivers. As they reached the low-lying tracts their rate of flow would gradually diminish, and finer-grained materialsfine silt and loam - would eventually be deposited. When we consider the great volumes of water descending to the low grounds, we cannot, indeed, escape from the conclusion that many wide areas in the plains during a glacial epoch must have been inundated, and in those slackwaters and temporary lakes the finer-grained fluvio-glacial sediments would tend to accumulate. We must also bear in view the probabilityI had almost said the certainty - of great derangements of the drainage having taken place in Middle Europe. In winter, when the rivers of that region were frost-bound, snow must frequently have drifted to great depths in the valleys, and the spring and summer thaws would often fail to remove these heaps. In this way the valleys might here and there become entirely filled with the blown and congealed snows of successive years, so as to compel the rivers in summer to rise in flood, and to reach levels which they might otherwise have been unable to attain. We have positive proof, indeed, that such accumulations of driftsnow actually did appear in extra-glacial regions, for some of them have persisted to the present day. The ice-formations of the Arctic coastlands, with their associated mammalian remains, certainly belong to the Glacial Period. They are simply the drifted snows, now converted into granular and massive ice, which accumulated in valleys and depressions outside of the glaciated regions. Protected under a covering of superficial detritus, alluvial matter, and peat, they have in those high latitudes persisted to the present day. Farther south, in Central and Western Europe, similar masses of congealed snow, as we have seen, appear to have accumulated, and may well have endured for some time after glacial conditions had passed away. In these temperate latitudes, 
however, they were bound ere long to melt, and allow the overlying alluvial deposits to settle down in the manner already described.

There are thus various lines of evidence which lead to the conclusion that during a glacial epoch the lower reaches of all the great valleys opening out from glaciated regions, as well as large tracts of the wide plains extending in front of the northern mer de glace, would be more or less drowned in temporary lakes of turbid water, over the beds of which a fine sediment of somewhat uniform character must have been deposited. And such is generally believed to be the origin of the materials of the löss. The löss, as we now have it, is a fluvio-glacial silt or loam, very largely re-assorted and re-arranged by the wind. Its history, therefore, is involved with that of the Ice Age, and we must consequently turn our attention to the unquestioned deposits of that period, with a view to discover, if we can, at what particular stage of it the glacial silts were worked over by the wind, and tundra and steppe faunas successively occupied the low grounds of Middle Europe.

Let us first, then, trace as briefly as may be the history of the glacial and interglacial deposits. Avoiding detail, we shall confine attention to the more salient features of the evidence, and try to picture the succession of events from the beginning to the close of glacial times.

The facts upon which geologists base their conclusion that a vast icesheet formerly covered much of Northern and North-western Europe, while great snow-fields and glaciers existed not only in the Alps, but in many of the minor mountain ranges of Central and even of Southern Europe, may be very briefly summed up.

First, we have the evidence supplied by morainic accumulations of all kinds-bottom moraines or boulder-clays and terminal moraines. Second, we have the proofs of former glaciation afforded by striated rocks and roches moutonnees, and by the crushed, broken, tumbled, and confused rock-surfaces that occur so frequently underneath the bottom or ground moraines. Third, we have the presence of certain remarkable ridges of gravel and sand which appear to have been formed in tunnels under the ice, and of enormous sheets of similar materials which have been spread out by the waters escaping from the terminal front of the inland ice of Northern Europe; while in all the great valleys leading down from the Alps and other glaciated mountains we see broad terraces of alluvial detritus which have been deposited by torrential streams and rivers. All those fluvio-glacial deposits when followed from the low grounds into the regions occupied by moraines are found to dovetail with the látter, and are consequently of contemporaneous origin.

By mapping rock-strix and noting the general trend of the erratics which constitute so large a portion of the ground moraines, we acquire a knowledge of the directions followed by the inland ice and the great glaciers. Not only so, but by tracing the horizontal and vertical distribution of glacial phenomena, we have been able to show what regions - were wholly ice-covered, to measure the thickness attained by ice-sheets and glaciers, and to estimate the angle of their surface-slope. It is, in short, quite possible now to draw maps of Europe which shall give a fairly accurate presentment of the aspect presented by our continent in 
glacial times. On maps of a sufficiently large scale, we can delineate not only the great inland ice of the north and north-west, but the snow-fields and numerous glaciers of the Alps and other mountainous tracts, together with the areas covered by fluvio-glacial deposits.

So much for what we may call the physical evidence. But this is not all, for associated with the true glacial accumulations occur in many places beds charged with the remains of arctic-alpine plants and animals. The evidence of fossil organic remains, therefore, fully supports the conclusions arrived at from a study of purely glacial phenomena. We know that arctic forms of life lived in our seas at the time of which I am speaking, and that the countries outside of the glaciated areas were then clothed and peopled by an arctic-alpine flora and fauna.

But, as if in contradiction of this evidence, certain other deposits, charged with the remains of temperate and southern species of plants and animals, appear intercalated among the true glacial accumulations. The study of these and of their relation to subjacent and overlying morainic and fluvio-glacial accumulations, has led to the conclusion that the Glacial Period was not one continuous period of arctic conditions, but a cycle or succession of alternating cold and genial epochs.

So far as we at present know, glacial conditions first supervened in latè Tertiary times - in the so-called Pliocene Period. In the earlier part of that period the European climate had been singularly genial. Warm seas, tenanted by many southern species of molluscs, washed the shores of the British area, while the land was clothed with a much more varied and abundant flora than we now possess. Great forests seem to have covered vast areas, occupying not only the plains and the river valleys, but extending far up the mountain slopes of such regions as France without much change of character. The same species indeed appear to have flourished equally well in Cantal and Central Italy. Some of these had come down from early Tertiary times, and were destined soon to become extinct; some again were special forms belonging to genera which in our day are exotic; others were species which have survived to the present in more southern and eastern regions : while yet others are still represented in Europe by identical or very closely allied species. Thus the flora of the Pliocene was connected both with the past and the present plant-life of Europe, while at the same time it had relations with the floras of distant southern and eastern regions-with Florida, the Canary Islands, China, and Japan. All the evidence thus implies for early Pliocene times an equable and uniform climate, which permitted the intimate.association in our continent of many plants, which are now no longer able to exist at similar elevations, or in one and the same latitude.

The mammalian life of Europe in early Pliocene times was in keeping with the flora. The deinotherium and mastodon still survived, and along with these were rhinoceroses, hippopotamuses, and elephants, and many cervine and bovine animals. Carnivores of extinct and still existing types and many monkeys were also present.

Such then was the character of the climate, and the aspect of the flora and fauna of Europe in pre-glacial times. The gradual approach of glacial conditions is evidenced by the fact that the percentage of northern 
and arctic shells in the upper Pliocene marine deposits increases from the lower to the higher members of the series. We note a gradual dying-out of southern species, and a gradual coming-in of northern forms, until at last the beds are charged with the remains of a truly arctic marine fauna. We have no direct evidence as to the terrestrial conditions which obtained in Britain and Ireland at that time. The climate, however, could not have been genial and temperate as it is now. The presence of an arctic fauna in our seas shows that our shores were washed by currents coming from the north, and not as at present from the south-west. Reasoning from the analogy of to-day, therefore, we might infer that the climate of our area was probably not unlike that of Labrador.

The traces of the first glacial epoch are more clearly read in the deposits of the continent. . An immense glacier at this time, fed from the uplands of Scandinavia, filled the basin of the Baltic. The bottom moraine of that great ice-flow is seen in the low grounds of Scania, in Southern Sweden, while its fluvio-glacial deposits have been detected at many places in North Germany. The Alpine Lands were contemporaneously covered with extensive snow-fields, and large glaciers descended the deep mountain valleys, to deploy upon the Vorländer, in Switzerland, and South Germany. The terminal moraines of these glaciers have been mapped out, and the general conditions of the epoch have been so well ascertained, that the position of the snow-line at the time has been determined. It is believed to have been upon an average some 4000 feet lower than now. While the valleys of the Alps were thus gorged with ice and the basin of the Baltic was occupied by an immense mer de glace, it is not probable that the higher parts of our islands could have escaped glaciation. We can hardly doubt that snow-fields and glaciers must also have existed here. No trace of these, however, has been or is ever likely to be detected. Direct evidence of the kind, if it ever did obtain, has been obscured or destroyed by the action of the much greater glaciers and ice-flows of later epochs.

In tracing the succeeding events in the geological history of Europe, I shall confine attention in the first place to the Alpine Lands, for it is in the low grounds at the base of those mountains that the relation of the löss to the glacial and fluvio-glacial deposits can be most clearly made out.

It has now been ascertained that glaciers have on three successive occasions filled the great mountain valleys of the Alps and descended to the low grounds. The earliest advance I have already described-this constitutes the first glacial epoch of Swiss geologists. It was followed by a long spell of genial conditions when the great glaciers melted away, and retired to the inner recesses of the mountains. Many relics of the flora of this genial epoch have been preserved. Thus in the valley of the Inn, near Innsbruck, certain deposits have yielded an assemblage of plants similar to that which we now meet with in the valleys of the mountain regions south of the Black Sea-most of the plants being existing species. The mean annual temperature of the regions in which that flora now flourishes is $57^{\circ}$ to $65^{\circ} \mathrm{F}$., while that of Innsbruck at present is only $47^{\circ}$. But in the genial epoch of which I speak, the flora in question flourished 
on the mountain slopes overlooking Innsbruck at elevations of 3600 to 3900 feet, where the mean annual temperature in our day does not exceed $40^{\circ}$. This is enough to show us that the climatic conditions of the Alpine valleys must formerly have been considerably more genial than at present. From this and similar evidence in other Alpine valleys we may safely infer that the retreat of the glaciers was the result of a great change of climate, and that during the first interglacial epoch the snow-fields and glaciers must have retired to the highest ridges of the mountains.

The plant-beds just referred to are not only underlaid but overlaid by bottom or ground moraines, the overlying moraines belonging to the second glacial epoch. It was during this epoch that the glaciers of the Alps attained their greatest development-the snow-line becoming depressed to 4700 feet below its present level. The glaciers now pusbed their way into the low grounds considerably beyond the limits reached by their predecessors in the first glacial epoch. That the second, like the first glacial epoch, was of long duration is shown by the amount of erosion effected by the ice-flows, and the enormous extent of their bottom and terminal moraines.

Overlying the ground moraines of that epoch we again come upon alluvial deposits in many places, which are crowded with the remains of a temperate flora-a flora resembling that of the low grounds of Switzerland and North Italy in our own days. It is obvious, therefore, that when such a flora flourished in the great valleys of the Alps the climate could not have been less genial than the present: the snow-line must have again retreated to a higher level, and the névés and glaciers were probably not more extensive than they are now. This constitutes the second interglacial epoch of Swiss geologists. Ere long it was followed by a third general advance of the glaciers, which once more reached the low grounds at the base of the Alps, but did not flow so far as their predecessors of the preceding or second glacial epoch. The snow-line of this third glacial epoch stood at an average level of about 4400 feet below the present.

Each glacial epoch was necessarily marked by profound glacial erosion, and the consequent formation of massive sheets of ground moraine in the lower reaches of the great valleys, and of huge terminal moraines at or opposite their mouths. Enormous quantities of shingle and gravel were at the same time swept outwards by the rivers escaping from the iceeach series of terminal moraines being thus closely associated with its separate and distinct set of fluviatile deposits. No difficulty is found in separating those successive accumulations of gravel. They form terraces lying one within the other at three successive levels. The highest rises upon an average 250-300 feet above the present rivers; the surface of the middle terrace is about 100 feet below the surface of the highest, and about the same distance above the level of the lowest terrace. Each terrace rests upon solid rock, and it is obvious, therefore, that the several epochs of gravel accumulation have been separated by epochs of active river erosion. : This remarkable valley-within-valley formation is clearly the result of climatic changes. The highest terrace indicates the action of flooded rivers escaping from the glaciers of the first glacial epoch. 
These glaciers then disappeared, or shrank into comparative insignificance, and an interglacial epoch of active valley erosion succeeded-the rivers cutting their way down for a hundred feet or more into the solid rocks. Next eame the second glacial epoch, and the lowered valley-bottom was again deeply covered with gravel. The glaciers of this stage then in their turn retired, and a second interglacial epoch supervened, when the rivers as before deepened their channels, working down through the older gravels, and excavating the underlying rocks. Thereafter the third glacial epoch ensued, and a new series of gravels was deposited at a lower level than the preceding accumulation. Lastly, this third glacial epoch passed away, and the rivers again trenched the fluvio-glacial gravels, the upper surface of which is now much above the reach of the greatest floods.

What relation, then, does the löss bear to the glacial and interglacial accumulations of the Alpine Lands? Fortunately to this question a definite reply can be given. It is dovetailed with the glacial deposits in such a manner as to show that its formation has taken place at successive epochs. Thus it occurs occupying an interglacial position between the accumulations of the first and second, and between those of the second and third, glacial epochs. When we pass down the valley of the Rhine a similar succession is encountered. In the wide plain lying between the Vosges and the Black Forest, löss is met with on the same geological horizons, overlying the gravel-terraces of the first and the second glacial epochs. Not only so, but even the youngest or lowest gravel-terrace (that of the third glacial epoch) is in like manner sheeted in löss. The löss on these three separate horizons is for the most part wind-blown, and exactly resembles that of Middle Europe generally, showing the same structure and arrangement, and containing a similar assemblage of organic remains.

To what extent each of these "horizons" of löss may be represented in the low grounds of Middle Europe we cannot definitely say. But as the materials of the löss are for the most part of fluvio-glacial origin, it is obvious that such accumulations must have been formed during each successive advance of the Alpine glaciers. As each glacial epoch passed away those accumulations were greatly modified by the wind, and drifted into the valleys that drain the Alps, where they were subsequently covered and to some extent preserved under the morainic and fluvioglacial deposits of the succeeding epoch of glacial advance. It seems probable, therefore, that the wind-blown löss of the low grounds of Middle Europe does not belong exclusively to any one particular stage of the Glacial Period. It is impossible, however, at present to divide it up into separate stages. But we may feel sure that if tundra and steppe faunas succeeded each other again and again in the valley of the Rhine, they could hardly fail to have done the same in the wide plains of Middle Europe.

It will be remembered that at the Schweizersbild, the deposits containing remains of tundra and steppe faunas rest immediately upon fluvio-glacial gravels. These gravels were laid down during the third glacial epoch. It is quite certain, therefore, that the faunas referred to

VOL. XIV. 
must have entered Switzerland after the retreat of the glaciers from the low grounds. But how long an interval may have elapsed between the disappearance of the glaciers and the advent of the lemmings and their congeners we cannot tell. All we know is that after the appearance of the tundra fauna in Switzerland, the climate, at first cold and arctic, gradually became less extreme, so that in time a steppe fauna, and afterwards a forest fauna, succeeded. In other words, no perceptible hiatus separates the present from the conditions that obtained when the reindeer hunter vanished from the Alpine Lands. He was succeeded by Neolithic man, just as the latter was followed by the men who used bronze and iron implements and tools. So far as the evidence of the Schweizersbild rock shelter is concerned, we should infer that no great alternations of cold and genial epochs followed after the final retreat of the great glaciers of the third glacial epoch. But, as we shall see presently, the tale told by that interesting rock shelter is incomplete. Certain considerable climatic changes did take place after the third glacial epoch had passed away. The evidence of such change, however, though not wanting in the Alpine Lands, is much more clearly displayed in North-western Europe. To the testimony yielded by the glacial and interglacial deposits of that region, therefore, we shall now direct attention.

It will be remembered that during the first glacial epoch a great Baltic glacier existed, and an arctic fauna lived in the North Sea. That epoch was succeeded by the first interglacial stage, when the southern part of the North Sea became dry land, and England was occupied by an abundant mammalian fauna-comprising hippopotamus, elephants, rhinoceros, horse, bison, boar, many kinds of deer, and a number of carnivores, including bears, hyæna, sabre-toothed tiger, wolf, fox, etc. The contemporaneous flora was temperate, resembling very much that which now exists in south-east England. In similar latitudes on the continent the same mammalian fauna flourished, while the flora was temperate, but suggestive of less strongly contrasted summers and winters than the present. A kind of insular climate, in short, seems to have characterised North Germany.

To this genial interglacial epoch succeeded the second and most extreme of all the glacial epochs. An enormous mer de glace then extended over all Northern and North-western Europe, from the British area in the west to the Urals in the east, and from Lapland in the north to the mountains of Middle Europe in the south. (See Map B.)

When these extreme conditions eventually passed away, the second interglacial epoch supervened, characterised, as the earlier one had been, by a genial temperate climate, by the presence in England and the continent of the great pachyderms and their congeners, and by the appearance of Palæolithic man.

This second interglacial epoch was in its turn succeeded by a third advance of the Scandinavian "inland ice," which once more coalesced with the mer de glace of the British area. It did not, however, flow so far as its predecessor. Nevertheless it reached the Valdai Hills in the east, the valley of the Elbe in the south, and covered all Seotland, the 
north of England, and the major portion of Ireland. This ice-flow was most probably contemporaneous with the third advance of the great glaciers of the Alps. (See Map C.)

It is noteworthy that the löss in North Germany nowhere overlies the morainic accumulations of the third glacial epoch. It does, however, cover the marginal area of the ground formerly invaded by the second and greatest mer de glace. This clearly shows that the löss of North Germany must belong, in part at least, to the second interglacial epoch. The fact that it everywhere avoids the regions over which the third great ice-sheet prevailed, does not, however, prove that tundra and steppe conditions did not supervene at a later date in Middle Europe. The evidence supplied by the Alpine Lands, and the great valleys that drain those lands, is quite conclusive of the contrary. There is no doubt whatever that the Palæolithic reindeer. hunters followed the chase in Middle Europe long after the third great Scandinavian mer de glace had retired from the plains of North Germany: The geographical distribution of the wind-blown löss shows that steppe conditions were restricted to a broad belt of land in Middle Europe. These conditions were rendered possible by the former greater extension of our continent into the Atlantic, when the major portion of the North Sea and the English Channel were dry land, and the British Islands formed part of the continental area.

Considerable climatic changes continued to take place after the passing of the third glacial epoch. These have left their traces in the Alpine Lands, but they are nowhere so clearly seen as in Northern and North-western Europe. Temperate conditions supervened in North Germany-the flora and fauna closely resembling those of the present. But eventually a relapse to glacial conditions followed, and from the Scandinavian snow-fields another invasion of North Germany took place. Norway, Sweden, and Finland were now once more shrouded in ice, and a great Baltic glacier came into existence, the gigantic terminal moraines of which are met with in Denmark, Schleswig-Holstein, and Prussia. The Scottish Highlands and other mountainous parts of the British Islands at the same time nourished local ice-sheets and large valley glaciers, which in many cases descended to the sea. The Alpine Lands in like manner witnessed a recrudescence of glaciation, large glaciers flowing into the great longitudinal valleys, but nowhere deploying as before upon the low grounds. It is to this stage, probably, that we should assign the tundra fauna of the Schweizersbild. (See Map D.)

The succession in that interesting rock sheiter has shown that as the severity of the climate relaxed, steppe and forest faunas successively followed the disappearance of the tundra forms. The climate of Europe generally became temperate, and immense forests overspread wide regions. It. was during the approach of these conditions, as we have seen, that Palæolithic man seems finally to have vanished, and the Neolithic races to have made their earliest appearance in Europe. The British Islands at this time formed part of the continent, and the Baltic existed as a great freshwater lake. The lower buried forests of our peat-bogs are among the conspicuous remains of this stage. Eventually, however, 
submergence ensued, the British Islands were severed from the continent, and the sea again invaded the Baltic basin. It is notable that the character of the marine fauna which at this stage lived off the coasts of Scandinavia and Britain is indicative of more genial conditions than now obtain. The climate, however, gradually became colder, the vertical and horizontal range of the forests was restricted, and snow-fields again appeared among the higher mountains of our islands. In Scotland glaciers here and there came down to the sea, and dropped their moraines upon the beaches then forming; the large majority, however, terminated inland. At that time the snow-line in North Britain ranged between 2000 and 2600 feet. Similarly, in Norway and in the Alps an advance of glaciers took place-the snow-line in Southern Norway being about 2400 feet, while in the Alpine Lands it seems to have averaged $\mathbf{7 5 0 0}$ feet, or some 1600 feet lower than the present.

Later climatic oscillations followed, but on a decidedly reduced scale. The effect of these was naturally enough most marked in North-western Europe, decreasing gradually southwards, and doubtless eventually fading away in the lower latitudes of the continent. It is not necessary for my present purpose to do more than briefly indicate the general character of these later changes so far as they affected our own area.

The local glaciers of the British mountains, some of which, as I have said, actually entered the sea, at last began to retreat. The climate became more genial, and so once more favoured the growth of forests, which in many places began to overspread the now dry peat-bogs, beneath which the trees of the earlier forest epoch lay entombed. Eventually, however, colder and more humid conditions returned, and small glaciers appeared in a few places amongst the loftiest heights of the Scottish Highlands. The position of the moraines of these glaciers indicates a height of 3500 feet for the snow-line. The forests now, as before, began to decay in many places, and the bog-moss and its allies again extended in all directions, and so, eventually, a second forest-bed became entombed in growing peat. It is needless to say that the evidence of these later changes is not restricted to Scotland. The bogs of the two sister countries, and of the corresponding latitudes on the continent, present us with precisely the same phenomena.

The present decayed aspect of the bogs in many places where they formerly flourished, and the fact that certain plants and groups of plants are once more beginning to invade such wastes, shows that we are now living under somewhat milder and less humid conditions.

Although these later climatic oscillations certainly affected the distribution of plants and animals to some extent in Northern and Northwestern Europe, yet the changes brought about were insignificant as compared with those which characterised the alternations of preceding glacial and interglacial epochs. The earlier cold and genial stages were strongly contrasted, and marked by great migrations of flora and fauna. But, as the strange cycle drew to a close, the contrast between glacial and interglacial phases became less and less pronounced, and gradually faded away into the present. The steppe fauna vanished from Middle Europe during the fourth interglacial epoch, and it never returned. The 
climatic oscillations that followed were on too. small a scale to induce great migrations, and thus the succeeding forest fauna retained its place. Hence in such a section as that seen in the rock shelter of Schweizersbild, we find no recognisable evidence of the climatic changes to which the buried forests and peat-bogs and the small local moraines of Northern and North-western Europe bear testimony. It is thus only by correlating and comparing the evidence over the widest area that we are able to get the story completed.

In fine, we have seen that tundras and steppes appeared at successive epochs in prehistoric Europe. The former were contemporaneous with the great ice-sheets and glaciers, while the latter came into existence when glacial conditions were passing away. The tundra and steppe conditions of our continent belong, in short, to that remarkable cycle of climatic and geographical changes known as the Ice Age or Glacial Period. Palæolithic man undoubtedly lived through both phases, for his relics and remains are found associated alike with the arctic lemmings and the succeeding steppe animals. Whether the reindeer bunter of Middle Europe ever came into contact there with Neolithic man we cannot tell. Were we to trust to negative evidence we should say he never did. But negative evidence cannot be trusted. It is quite possible that the two races may have met and even commingled, but of this no proof is forthcoming. The strong hiatus that separates the Old Stone and the New Stone epochs in Western and North-western Europe has not yet been bridged over in Middle and Southern Europe. When last we see Palæolithic man he is hunting the reindeer and the mammoth in the Danubian steppes. His Neolithic successor seems not to have appeared in Middle Europe before steppe conditions had passed away and a forest flora and fauna had become dominant.

\section{FROM ASTROLABE TO QUADRANT.}

WE know that the great nautical discoverers were often out in their reckoning, and that therefore it is not always easy to identify certain places which they sighted or where they landed. And that this is so is not to be wondered at, when we consider the instruments at their disposal for the determination of positions.

One of the oldest instruments employed in taking astronomical observations at sea was the Astrolabe. This was not the armillary sphere described by Ptolemy, but a much simpler instrument consisting of a flat ring which could be suspended freely by means of a handle attached to its edge. Its upper quadrants were graduated from 0 up to $90^{\circ}$ at the point of suspension. An alidade, pivoted at the centre of the ring, was furnished with two holes or slits (at A and B in fig. 1) lying in a line with the centre. When the altitude of the sun was taken, the astrolabe was held up and turned round until the rays of the sun fell 